\title{
A Five Years Prospective Study of Dentigerous Cyst
}

\author{
MIHAELA MITREA ${ }^{1}$, ALLIA DMOUR ${ }^{1}$, DRAGOS VALENTIN CRAUCIUC², SIMONA NICULESCU³, ROXANA GABRIELA COBZARU4*, \\ LOREDANA LILIANA HURJUI ${ }^{4}$ \\ ${ }^{1}$ Grigore T. Popa University of Medicine and Pharmacy, Departament of Morphofunctional Science I, 16 Universitatii Str., 700115, \\ lasi, Romania \\ ${ }^{2}$ Institute of Legal Medicine, 4 Buna Vestire Str., 700455, Iasi, Romania \\ ${ }^{3}$ Grigore T. Popa University of Medicine and Pharmacy, Department of Mother and Child Medicine, 16, Universitatii Str., 700115, \\ lasi, Romania \\ ${ }^{4}$ Grigore T. Popa University of Medicine and Pharmacy, Department of Morphofunctional Science II, 16, Universitatii Str., 700115, \\ Iasi, Romania
}

\begin{abstract}
The purpose of this 5-year study (2002-2007) was to evaluate 90 cases of dentigerous cysts that were identified in a private dental office in terms of distribution by region (maxillary-anterior region, mandibular), age, sex, and surgical removal technique chosen. We also compared the 45 cases where PRGF was applied after cyst extirpation with the other 45 cases that were allowed to heal periosteum. We noticed that in cases where the PRGF clot was applied in the cystic geography, bone regrowth was achieved much faster.
\end{abstract}

Keywords: dentigerous cyst, enucleation, bone regeneration, PRGF

Odontogenic cysts are derived from odontogenic epithelium. It is developed by the enlargement of the follicular space that encloses the whole or part of the crown of an unerupted tooth. It occurs more frequently in males and is more commonly present in the mandible [1,2]. Most of them are more defined by their location and imaging than by its histologic criteria. These cysts are considered the most common osseous-expansile and/or destructive lesion affecting jaws. Most common types include radicular, dentigerous cysts and keratocysts, respectively; together accounting for more than $85 \%$ of all jaw cysts. The radicular type accounts for most odontogenic cysts, while dentigerous constitute more than $20 \%$ of all cysts, being the commonest odontogenic cyst of developmental origin [3-5].

Most dentigerous cysts are asymptomatic and their discovery is usually an incidental finding on radiography. Imaging is very important for diagnosing cysts based on panoramic radiography, $\mathrm{CT}$ films and cone beam $\mathrm{CT}$. They provide an idea about the extent and bony wall condition, preoperatively. Postoperative imaging is also needed for detecting the rate of regression and bone regeneration. Postoperative histopathology is the mainstay for final diagnosis and exclusion of additional pathologies. Thus, jaw cysts diagnosis and subsequent definitive managementrely on a radiological-pathological description $[6,7]$.

The management of such cases extremely varies from aggressive lines as radical resection to minimal invasive procedure like simple marsupialization, together with endodontic management of the affected teeth to minimize the risk of recurrence [8]. The surgical approach includes extraoral and intraoral approach. The most commonly used extraoral approach was submandibular and preauricular access. The external access has the advantage of good exposure of the surgical site but may result in complications, such as extraoral scarformation, damage of joint components, facial nerve injury in case of preauricular access or damage of marginal mandibular branch of the facial nerve in case of submandibular access. The intraoral approach may avoid the problems but provides a small surgical site [9].
Surgical treatment of dentigerous cyst usually includes marsupialization and enucleation along with or without the extraction of the impacted tooth. Enucleation of the lesion along with or withoutremoval of associated is done when the cystissmall, no vital adjacentstructures, tooth, notin a favorable position, need accelerated healing and no recurrence. Enucleation with alter the normal tooth development and in certain circumstances especiallyin children, the involved tooth should be given a chance to erupt and large cystif enucleated result in pathological fractures and damage to the viral structures and tooth buds also [9]. Marsupialization is done in cases when the size of the cysts is large, in a young patient with developing tooth gums, in elderly, debilitated patient, cyst proximity to the vital structures if the tooth is in a favorable position and space is available, it will permit the eruption of unerupted tooth. Major disadvantages of marsupialization are that the pathological tissue is left in situ without through histological examination, prolonged follow-up visits, healing time and periodic irrigation of the cavity $[10,11]$.

If the tooth extraction is necessary, post extraction there is loss in dimensions both horizontal and vertical planes in the residual alveolar ridge. So, there is need for post bonegrafting procedure. This grafting restores the proper volume, function and esthetic of the post extracted socket. PRGF having autogenous growth factors can hasten socket wound healing after tooth extraction and increased bone fill and reduced bone resorbtion and periodontal regeneration[11].

\section{Experimental part \\ Material and methods}

During 2002-2007, in a private practice, we found 90 cases of dentigerous cysts, 80 (88.88\%) of which were localized to the jaw in the canine-premolary region, and $10(11.11 \%)$ of them at the level of mandible, at molar level 3 . Of the total of 90 cysts, 50 ( $55.55 \%$ ) were found in men and 40 (44.44\%) in women.

Of the 90 cases of dentigerous cysts cases, 85 were removed by the intraoral approach and 5 cases were operated by extraoral approach.

In terms of age in the decade 10-19 years, 35 cases were found, in the $20-29$ decade 20 cases were found, in

*email: roxanabahnea@yahoo.com; Phone: (+40)744533723 
the 30-39 decade 18 cases were found, and over 40 years were found 17 cases were found.

In the decade 10-19 years, of the 35 cases, 30 were found in men and 5 in women, 29 presented the bucal cortical expansion alongside radiological examination wich revealed a unilocular radiolucency with well-defined border surronding the crown of on unerupted tooth over 3 centimeters and 6 cases with pain.

In the 20-29 decade, of the 20 cases, 18 were found in men and 2 in women, 16 of them presented the bucal cortical expansion alongside radiological examination wich revealed a unilocular radiolucency with well-defined border surronding the crown of on unerupted tooth over 3 centimeters and 4 cases with pain.

In the 30-39 decade, of the 18 cases, 14 were found in men and 4 in women, 16 of them presented the bucal cortical expansion alongside radiological examination wich revealed a unilocular radiolucency with well-defined border surronding the crown of on unerupted tooth over 3 centimeters and 2 cases with pain.

Over the age of 40, 17 cases were found, 15 of them in males and 2 in females, 14 of them presented the bucal cortical expansion alongside radiological examination wich revealed a unilocular radiolucency with well-defined border surronding the crown of on unerupted tooth over 3 centimeters and 3 cases with pain.

From the point of view of surgery, in 45 of the cases PRGF (plasma rich in growth factors) clotting was applied in the cystic geography, with faster bone regeneration being observed, while in the other 45 cases the healing was left based on the periosteum.

Following the marsupialisation and enucleation surgery, the extracted tissues were stained with HE (hematoxylineosin) and analyzed by microscope.

\section{Results and discussions}

Dentigerous cyst most commonly occurs in people between 10-30 years of age [12]. In this study most cases was in the decade 10-19 years and the most advanced age of pacients was 54 years, dentigerous cyst at this age is not very common (table 1). Dentigerous cyst is the second most

Table 1

INCIDENCE BY AGE GROUP

\begin{tabular}{|c|c|c|}
\hline Age group & Number of cases & Percentage \\
\hline $10-19$ & 35 & $38.89 \%$ \\
\hline $20-29$ & 20 & $22.22 \%$ \\
\hline $30-39$ & 18 & $20.00 \%$ \\
\hline $40+$ & 17 & $18.89 \%$ \\
\hline Total & 90 & $100 \%$ \\
\hline
\end{tabular}

common odontogenic cyst in adults and accounts for half of those in children and adolescents. It is estimated that $1 \%$ of impacted teeth develops dentigerous cyst. It is mainly associated with mandibular third molar. Maxilary canine, maxillarythird molarand mandibular premolar are involved in the decreasing order of frequency [12,13]. In this study, the age of patients ranged from 10 years to 54 years. The number of patients with dentigerous cysts over 40 years was 17 (fig. 1). Zang LL et al., Lin HP and John AV et al reported an age range between $10-29$ years, $6-99$ years and $17-89$ years respectively [14-16]. These findings suggested that the dentigerous cysts can occur over a wide age range. This is because the mandibular third molars and the maxillary permanent canine are the most commonly impacted teeth and are most frecquently associated with dentigerous cysts. Development of these cysts occur at an early at the time of

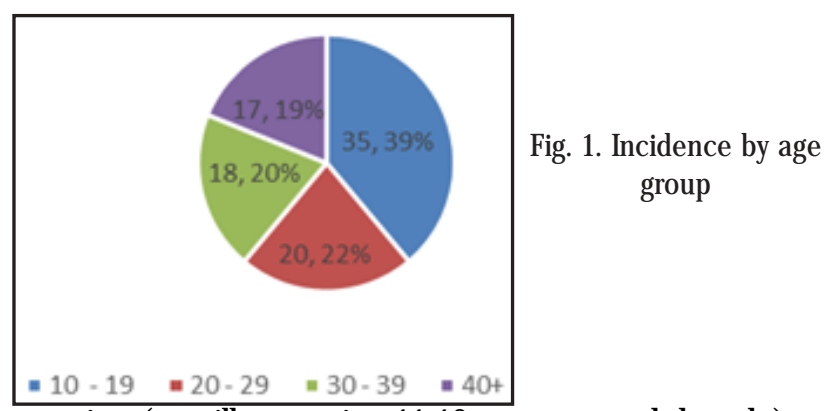

eruption (maxillary canine 11-12 years,second decade) and mandibular molars 17 to 21 years (second and third decade). That is attributed to the fact that eruption tooth exert pressure on the folicle leading to cyst formation [16]. Its prevalence in fifth decade was reported by ones AV et al wich differs from findingd of other studies in the literature [16].

Our study was in agreement with the literature showed a much higher incidence in males compared to females. (table 2, fig. 2) [1, 2]. The reason for the gender predilection is not clear. Daley et al suggested that it may be related to a smaller jaw size and a greater tendency for prophylactic extraction of third molars in females [17].

Table 2

INCIDENCE BY AGE GROUP AND SEX.

\begin{tabular}{|c|c|c|c|c|}
\hline Age group & Male & Percentage & Female & Percentage \\
\hline $10-19$ & 30 & $85.71 \%$ & 5 & $14.29 \%$ \\
\hline $20-29$ & 18 & $90.00 \%$ & 2 & $10.00 \%$ \\
\hline $30-39$ & 14 & $77.78 \%$ & 4 & $22.22 \%$ \\
\hline $40+$ & 15 & $88.24 \%$ & 2 & $11.76 \%$ \\
\hline Total & 77 & & 13 & \\
\hline
\end{tabular}

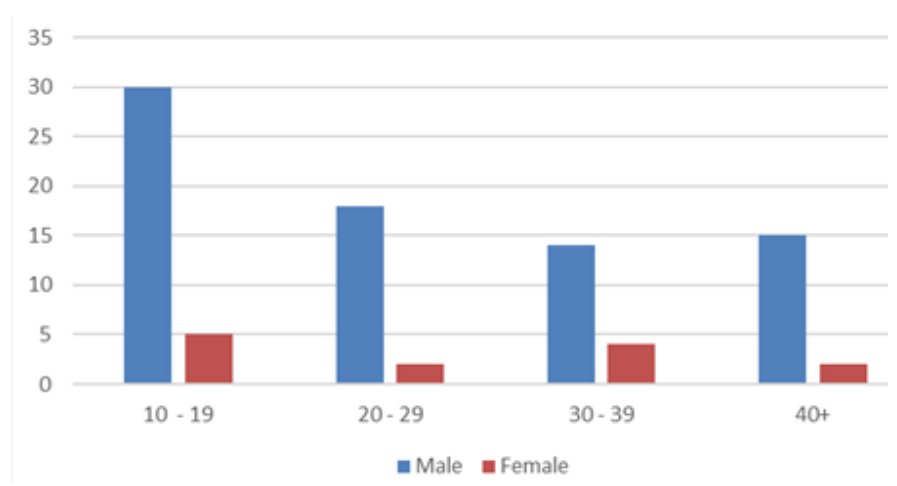

Fig. 2. Incidence by age group and sex

In relation to localisation, a preference for maxilla (80 cases, $88,89 \%$ ) especially anterior region, followed by mandibular (10 cases, $11.11 \%$ ) posterior region was observed (table 3, fig. 3). These figures are in agreement with very few authors but contrast to the findings of others in the literature [18-20] who reported mandible being the most freguently affected site $[14,15]$.

Dentigerous cysts is usually diagnosed on routine dental examination because most of time it is asymptomatic, although these cysts can enlarge and cause bone

Table 3

LOCALISATION OF DENTIGEROUS CYST

\begin{tabular}{|c|c|c|}
\hline Localisation & Number of cases & Percentage \\
\hline Maxilla & 80 & $88.89 \%$ \\
\hline Mandible & 10 & $11.11 \%$ \\
\hline Total & 90 & $100 \%$ \\
\hline
\end{tabular}




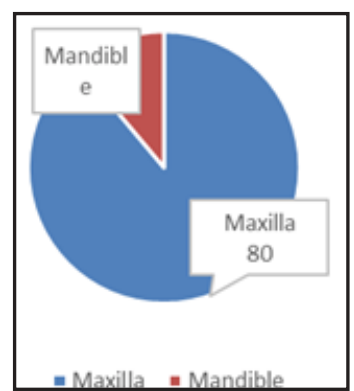

Fig. 3. Localisation of dentigerous cysts, percentage

expansion, tooth displacement and even pathological fracture (fig. 4). Dentigerous cysts become painful if secondary infected. Radiographhically, dentigerous cyst is a well-defined unilocular radiolucency surrounding the crown of an impacted tooth [21].

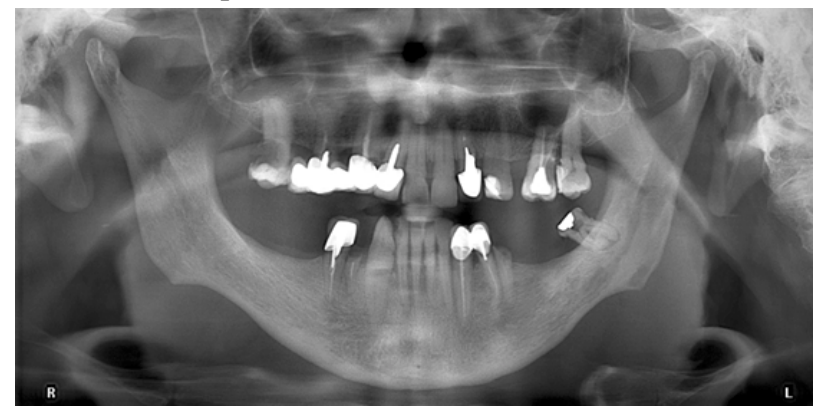

Fig. 4. Dentigerous cyst located at the level of a maxillary canine

Diagnosis of dentigerous cysts is straight forward when it is associated with unerupted teeth. However, notall lesion associated with unerupted teeth are dentigerous cysts. Unerupted tooth may be seen associated with other odontogenic lesion like odontogenic keratocyst, ameloblastoma, especially unicystic ameloblastoma and odontogenic tumor. Conventional radiographs and CBCT may be play an important role in differentiating these lesions from dentigerous cysts [22].

Dentigerous cyst developd by accumulation of fluid either between reduced enamel epithelium and enamel or inbetween the layers of the enamel organ. Such fluid accumulation occurs as a result of presure exerted by the erupting tooth on the follicle that obstructs the venous outflow and hence induce rapid transudation of serum across the capillary wall. Dentigerous cysts arises by the breackdown of the proliferating cells of the follicle after impeded eruption. These breakdown products increase the osmotic pressure, hence result in cyst formation. The sweeling was associated with expansin of buccal and lingual cartical plates [23]

In accordance with the literature, in this study we found the exponential vestibular corticals presentin all age groups while the pain occurred as a result of the secondary infection in a lower percentage (table 4, fig. 5).

The method of surgical approach includes marsupialization and enucleation along with or without the extraction of the impacted tooth. Enucleation of the lesion along with or without removal or associated is done when the cyst is small, no vital

Table 4

EXPANSION BY AGE GROUPS OF THE CORTICAL BONE

\begin{tabular}{|c|c|c|c|c|}
\hline Age group & $\begin{array}{c}\text { Expansion } \\
\text { of corticals }\end{array}$ & Percentage & Pain & Percentage \\
\hline $10-19$ & 29 & $82.86 \%$ & 6 & $17.14 \%$ \\
\hline $20-29$ & 16 & $80.00 \%$ & 4 & $20.00 \%$ \\
\hline $30-39$ & 16 & $88.89 \%$ & 2 & $11.11 \%$ \\
\hline $40+$ & 14 & $82.35 \%$ & 3 & $17.65 \%$ \\
\hline Total & 75 & & 15 & \\
\hline
\end{tabular}

Local manifestation

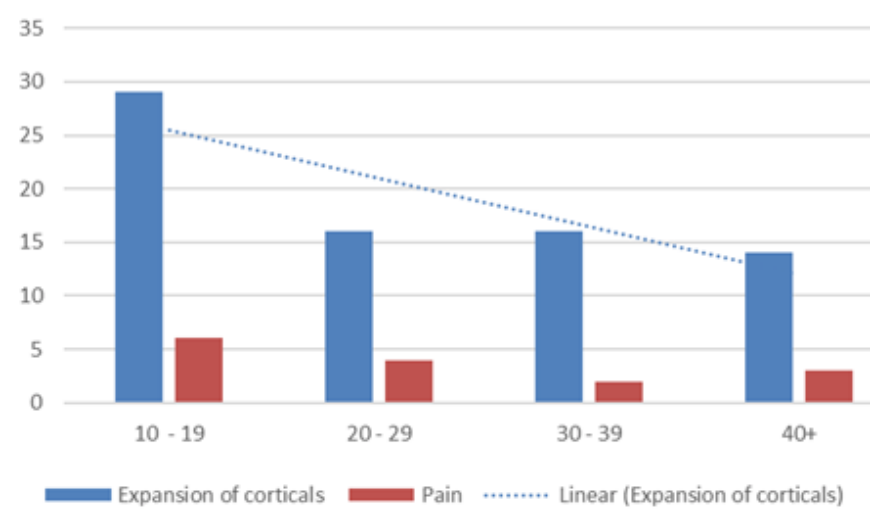

Fig. 5. Cortical expansion by age groups along with pain

adjacent structures, tooth, not in a favorable position, need accelerated healing and no recurrence. Enucleation with alter the normal tooth development and in certain circumstance especially in children, the involved tooth should be given a chance to erupt and large cyst if enucleated result in pathological fracture and damage to the vital structures and tooth buds also $[24,25]$. According to the literature, we performed the enucleation of 30 cases of dental cysts during 10-19 years.

Marsupialization is done in cases when the size of the cyst is large, in a young patient with developing tooth gums, in elderly, debilitated patient, cyst proximity to the vital structures if the tooth is in a favorable position and space is available it will permitthe enuption of unerupted tooth. Major disadvantages of marsupialization are that the pathological tissue is left in situ without through histological examination, prolonged irrigation of the cavity. Althought dentigerous cystis considered a benign lesion, its epithelial lining has the potential to undergo neoplastic change and development of squamous cell carcinoma [23-25].

Combined marsupialization and enucleation was done in 46 cases of dentigerous cysts in agreement with the literature to reduce morbidity, accelerated healing, development of a thickened cyst lining which makes enucleation easier and allows histopatological examination of residual tissue.

Histologically, dentigerous cysts may or may not show inflamation. It usually shows a thin fibrous cyst wall consisting of young fibroblast separeted by stroma and ground substance. Epithelial lining consists of 2-4 layers of flat or cuboidal cells. Characteristically, epithelial lining is not keratinized. Cystic capsule is fibrous to fibrocellular and showed presence of chronic inflammatory cells mainly lymphocytes, cholesterol clefts and multinucleated giant cells in secondary infected dentigerous cysts. Other features may be present calcification, odontogenic rests and areas of hyalinisation [26]. In this study we found the cystic lesion of the inner wall made up of a not keratinized epithelium, deep-creased epithelium (yellow arrow) disposed on fibrous connective tissue, densely collagenized with numerous fibrocytes and infiltrated by diffuse (white arrow), (fig. 6).

Another histological analysis, we did in the case of a female patient for 12 years, cystic lesion whose wall is partially taped by a not keratinized, irregular, deep-creased squamous epithelium (white arrow) disposed on fibrous connective tissue with numerous fibrocytes, collagen fibers and rare blood vessels but with the presence of mononuclear inflammatory elements, predominantly plasmocite, diffuse (fig. 7a). The same case, another area: another section of the same lesion reveals small portions of the cystwall, represented by a not keratinized squamous 


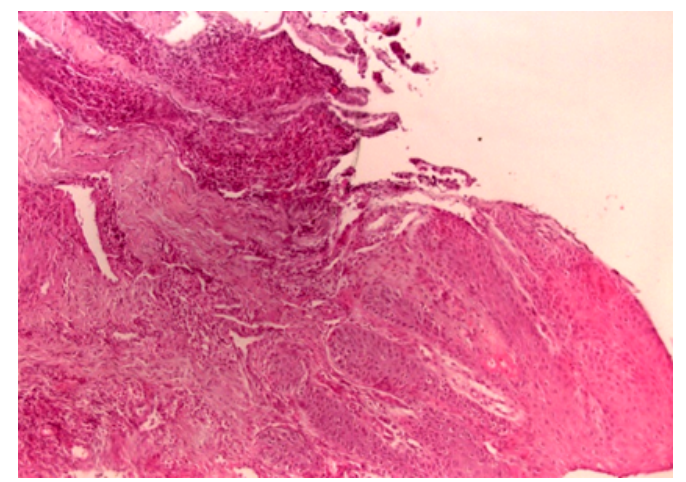

Fig. 6, BV, M, 54 years: dentigerous cyst , hematoxylin-eozin (HE, x10)
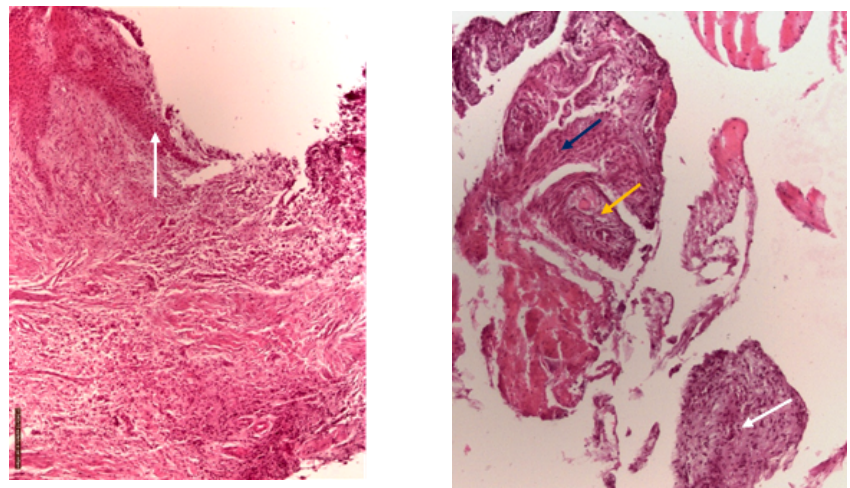

Fig. 7. A. MA, $f, 12$ ani: dentigerous cyst $(H E, X 10)$. b. the same case, another area ( $\mathrm{HE}$,

epithelial epithelium (blue arrow), disposed on conjunctivovascular neoformation infiltrated with mononuclear inflammatory elements (yellow arrow) another small fragment of the fibrous capsule, also infiltrated by mononuclear inflammatory elements (white arrowhead). These tissue fragments are included in the cyst content, made up of a collection of altered red blood cells with rare leukocytes (fig. 7b).

After masupialization and enucleation of cysts in 45 of the cases the cystic geode healing was left on the periosteum and in the other 45 cases the PRGF (Plasma Rich in Growth Factor) clot was applied locally to the cystic geode observing the acceleration of the bone regeneration. A platelet-fibrin material which does not use bovine trombine as an activator, has been described as a plateletrich fibrin matrix. PRGF release cytokines TGF (transforming growth factor), PDGF (platelet-derived growth factor), VEFG(vascular endothelial growth factor) and EGF (epidermal growth factor) wich play a critical role on angiogenesis and tissue healing and cicatrization [27-30].

\section{Conclusions}

Dentigerous cyst is the second most common odontogenic cyst in adults and accounts for half of those in children and adolescents. In this study, the age of patients ranged from 10 years to 54 years.

Development of these cysts occur at an early at the time of eruption (maxillary canine 11-12 years,second decade) and mandibular molars 17 to 21 years (second and third decade).

The highest prevalence of dental cysts is in men compared to women.

In relation to localisation, a preference for maxilla especially anterior region, followed by mandibular posterior region was observed.

Combined marsupialization and enucleation of dentigerous cysts accelerated healing, development of a thickened cyst lining which makes enucleation easier and allows histopatological examination of residual tissue.

Histologically, dentigerous cysts may or may not show inflamation. It usually shows a thin fibrous cyst wall consisting of young fibroblast separeted by stroma and ground substance. Characteristically, epithelial lining is not keratinized.

The application of PRGF in the cystic geodetic stimulates bone healing.

\section{References}

1.MOTAMEDI MH, TALESH KT, Br Dent J 198, 2005, p.203-206.

2.AMI BALI, DEEPIKA BALI, ASHUTOSH SHARMA, NAGESHWAR IYER, Indian J ournal of Oral Sciences 3(1), 2012, p.53-58.

3.DALEY TD, WYSOCKI GP, PRINGLE GA, Oral Surg Oral med Oral Pathol 77(3), 1994, p.276-280.

4.DE AZAMBUJA BERTI, S.POMPERMAYER AB, SOUZA PH, TANAKA OM, WESTPHALEN VP, WESTPHALEN FH, Am J Orthod Dento-facial Orthop 137(5), 2010, p.690-693.

5.MOHAMED ABDELWAHAB, AHMED MUSAAD ABD ELFATTAH, YASSER W, KHAFAGY, AHMED EL-DEGWI, Auris Nasus Larynx 45, 2018, p.578584.

6.ODUFUWA B, ROSE GE, Arch Ophtalmol 119(10), 2001, p.1560-1561. 7.MANOR E, KACHKO L, PUTERMAN MB, SZABO G,BODNER L, Int J Med 9(1), 2012, p.20-26.

8.CHAPELLE KA, STOELINGA PJ, DE WILDE PC, BROUNS J J, VOORSMIT RA, Br J Oral Maxillofac Surg 42(5), 2004, p.381-390.

9.ASHRAQ YAQOOB, TARIQ MAJID WANI, JUNAID ASHRAF, GOWHAR YAQOOB, NUSRAT YAQUB, Dentistry and Medical Research 2(2), 2014, p. 49-52.

10.MURAKAMI A, KAWABATA K, SUZUKI A, MURAKAMI S, OOSHIMA T, Pediatr Dent 17, 1995, p.372-374.

11.MAYTE BUCHBENDER, FRIEDRICH W.NEUKAM, RAINER LUTZ, CHRISTIAN M, SCHMIT, Oral and Maxillofacial Surgery 5(125), 2018, p.399-406.

12.AZIZ SR, PULSE C, DOURMAS MA, ROSER SM, J Oral Maxillofac Surg 60, 2002, p.457-459.

13.BATHIA SK, COLLARD M, DIVCIC D,HUNTER L, Dent Update 36, 2009, p.374-376.

14.ZHANG LL, YANG R, ZHANG L, LI W, MACDONALD-JANKOWSKI D, POH CF, Int J Oral Maxillofac Surg 39(9), 2010, p.878-882.

15.LIN HP, WANG YP, CHEN HM, CHENG S), SUN A, CHIANG CP, J Oral Pathol Med 42(6), 2013, p.462-467.

16.J ONES AV,CRAIG GT,FRANKLIN CD, J Oral Pathol Med 35(8), 2006, p.500-507.

17.DALEY TD, WYSOCKI GP, PRINGLE GA, Oral Surg Oral Med Oral Pathol 77(3), 1994, p.276-280.

18.YEO JF, ROSNAH BZ,TI LS, ZHAO YY, NGEOW WC, Malaysian J Pathol 29(1), 2007, p.41-47.

19.AROTIBA JT, LAW OYIN JO, OBIECHINA AK, East Afr Med 75(11), 1998, p.664-666

20.BOON LC, Mal J Surg 9, 1990, p.82-87.

21.SHAFER WG, HINE MK, LEVY BM, Shafer s textbook of Oral Pathology, 6 th ed.Amsterdam. Elsevier, 2009, p.254-258.

22.PINTILICIUC SERBAN, V., MITREA,M., SINDILAR, A.,CRAUCIUC, D.V., NICULESCU, S., LUPUSORU, R.V., HURJUI, L.L., Rev Chim. (Bucharest). 69, no. 8, 2018, p. 2054-2060.

23.BENN A, ALTINI M, J Oral Maxillofac Surg 59, 2001, p. 1094-1096.

24. AYDIN U, YILMAZ HH, YILDRIM D,Dentomaxillofac Radiol 33, 2004, p.164-169.

25.TUMER C, ESET AE, ATABEK A, Quintessence Int 33, 2002, p. 231233.

26.REKHA KRISHNAPILLAI,KURIAN PUNNOOSE, Journal of Clinical and Diagnostic Research 12(2), 2018, p.14-17.

27.CHANG I, TSAI C, CHANG Y, J Biomen Mater Res 95(1), 2010,327332.

28.TEUSAN, A, LUPUSORU, R, $V_{1,}$ JELIHOVSCHI, I., et.al, Rev Chim. (Bucharest), 67, no. 3, 2016, p.476.

29.JELIHOVSCHI, I., DROCHIOI, C., BADESCU, A.C., et. Al, Rev Chim. (Bucharest), 68, no. 12, 2017, p.2853.

30.BUTCOVAN, D., LUPUSORU, C.E., BARAN, D., et.al, Rev Chim. (Bucharest), 67, no. 10, 2016, p.2012. 